УДК 629.442.3:621.436

Д-р техн. наук Д.С. Жалкін

Doct. of techn. sciences D.S. Zhalkin

\title{
МОДЕЛЬ ДЛЯ ВИЗНАЧЕННЯ СЕЗОННИХ ЗМІН ПОКАЗНИКІВ ВИКОРИСТАННЯ ЕНЕРГЕТИЧНИХ УСТАНОВОК ТЕПЛОВОЗІВ
}

\section{MODEL FOR SEASONAL CHANGES IN PERFORMANCE IS THE USE OF POWER PLANTS LOCOMOTIVES}

\begin{abstract}
Постановка проблеми. Головним напрямком покращення ефективності системи ТО та ПР є створення оптимальної стратегії управління нею на основі застосування нових методів прогнозування та аналізу показників використання енергетичних установок (ЕУ) тепловозів. Одержана модель дозволяє визначити зміни показників використання тепловозів у різні сезони року $[1,2]$ та вирішити важливу науково-технічну проблему підвищення надійності роботи ЕУ.
\end{abstract}
Аналіз останніх досліджень

і публікацій. Роботи 3 оптимізації системи ТО та ПР шляхом удосконалення методів прогнозування показників ефективності експлуатації тягового рухомого складу на основі багатофакторного регресійного аналізу відомі. У той же час зміна показників використання ЕУ тепловозів за сезонами експлуатації супроводжується зміною не тільки середнього рівня, але й значною зміною дисперсії [3].

Виділення невирішених раніше частин загальної проблеми. Традиційний аналіз графічних залежностей динаміки зміни показників надійності ЕУ тепловозів у часі та отриманих регресійних рівнянь не дозволяють кількісно визначити сезон, у який спостерігається збільшення чи зменшення числа несправних тепловозів. Процес прогнозування та аналізування показників надійності ЕУ тепловозів вимагає розроблення багатофакторної математичної моделі динаміки їх зміни у часі.

Мета статті. Моделювання та аналіз процесів зміни показників використання ЕУ тепловозів 3 метою розроблення технології сезонного корегування процесів технічного обслуговування (ТО) та ремонту (ПР).

Виклад основного матеріалу дослідження. У процесі експлуатації ЕУ тепловозів показники їх використання й надійності роботи зазнають змін. Ці коливання пояснюються старінням локомотивного парку, зміною умов експлуатації й частково зміною сезонної експлуатації. Зміну рівня надійності ЕУ тепловозів зручно описувати за допомогою інтегрального показника - коефіцієнта технічного використання $K_{\text {тв }}$ 


$$
K_{T B}=\frac{\sum_{1}^{r} t_{i}}{\sum_{1}^{r} t_{i}+\sum_{1}^{r} t_{n i}},
$$

де $t_{n i}$ - час вимушеного простою після $i$-ї перерви в роботі;

$n$ - число перерв у роботі, включаючи TО і ПР.

Завданням проведеного аналізу було, з одного боку, встановлення тісноти зв'язку між $K_{\text {тв }}$ і показниками використання ЕУ тепловозів, включеними в модель, а 3 другого - визначення внутрішньогрупових кореляцій у фіксований момент часу $t$. При подібному підході дане завдання можливо вирішити на основі однофакторного дисперсійного аналізу, фактором групування у якому виступає сезон експлуатації тепловозів (місяць року). У той же час, як показують результати спостережень [3], зміна $K_{\text {тв }}$ за сезонами експлуатації супроводжується зміною не тільки середнього рівня, але й значною зміною дисперсії. Вирішення викладеного вище завдання можливе на основі регресійних моделей зі змінною структурою та стохастичними пояснювальними змінними. $\mathrm{y}$ цьому випадку функція регресії $y=f(x)+\varepsilon_{x}$ розуміється, як умовне математичне очікування випадкової величини $y$ при значенні параметрів, зафіксованих на рівні $x$, при зміні в часі якісних факторів (сезону експлуатації), у результаті чого відбуваються стрибкоподібні зрушення в структурі аналізованих зв'язків [4]. Наявність стохастичних пояснювальних змінних накладає додаткове обмеження на регресійну модель, а саме: вимогу статистичної незалежності $x$ від регресійних залишків $\varepsilon_{x}$ i незалежності розподілу $x$ від оцінюваних параметрів моделі. Неоднорідність вихідних статистичних даних ураховується шляхом уведення в модель регресії фіктивних змінних, які відбивають вплив на результуючий показник $у$ якісних змінних. Урахування впливу супутніх змінних здійснюється шляхом уведення в праву частину регресійного рівняння бінарних змінних $z_{i, j}$, тобто змінних, які набувають одне 3 двох можливих значень (1 або 0). Для змінної, що має $k_{i}$ градацій, ставиться у відповідність $k_{i-1}$ бінарних змінних. У випадку визначення впливу сезонної експлуатації на надійність тепловозів було уведено 12-1=11 бінарних змінних, тобто один 3 місяців року в цьому випадку $\epsilon$ базою для порівняння з кодом $(0 ; 0)$.

Загальний вид регресійної моделі 3 фіктивними змінними для розглянутого випадку сезонної експлуатації:

$$
y=a_{0}+\sum_{1}^{q} b_{i} x_{i}+\sum_{q+1}^{m} \sum_{1}^{11} a_{i j} z_{i j}+\varepsilon_{x} .
$$

де коефіцієнти регресії моделі характеризують:

$b_{i}-$ чистий ефект впливу фактора $x_{i}$;

$a_{i j}$ - вплив $k$-ї градації $r$-го фактора $(k \neq r)$ на змінну $y$, тобто це різниця середніх значень функції $y$ між $k$-ю градацією та градацією, що взята за базу порівняння.

Відсутність статистичного впливу змінних $z_{i j}$, уведених у модель 3 метою урахування ефекту сезонності, на функцію $y$ означає відсутність сезонності у вихідних даних, і навпаки, значущість коефіцієнтів регресії при цих змінних дозволяє оцінити напрямок і величину цього впливу.

Розглянута методика регресійного аналізу застосована для аналізу даних про зміну $K_{\text {тв }}$ ЕУ тепловозів, що наведені на рисунку. Для урахування впливу зміни показників використання ЕУ тепловозів і

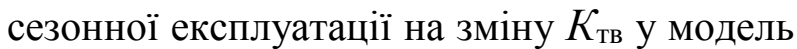
спочатку уведено шість факторів - простій на ТО-3, год; трудомісткість ТО-3, людгод; простій на ПР-1, год; трудомісткість ПР-1, людгод; інтенсивність надходження ЕУ тепловозів на позапланові ремонти 
од/10 ремонтах, год. Дані збиралися на основі існуючої статистичної звітності і усереднювались у межах місяця року. Значущими на підставі $t$-критерію визнані 4 фактори: простій на позапланових ремонтах, простій на ПР-1, інтенсивність надходження на позапланові ремонти й трудомісткість ТО-3. Коефіцієнт детермінації $R^{2}$ дорівнює 0,912 , тобто включені в модель фактори пояснюють

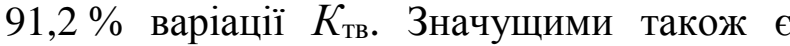
коефіцієнти регресії при фіктивних змінних, які відповідають березню й листопаду. Їхня величина й знак дозволяють зробити висновок про зниження $K_{\text {тв }}$ у ці періоди експлуатації відповідно на 4,6 та 13,9\%.

Проведена перевірка залишків моделі показала, що значення критерію $D W=2,12$ не перевершує критичного значення [5], що також свідчить про адекватність моделі.

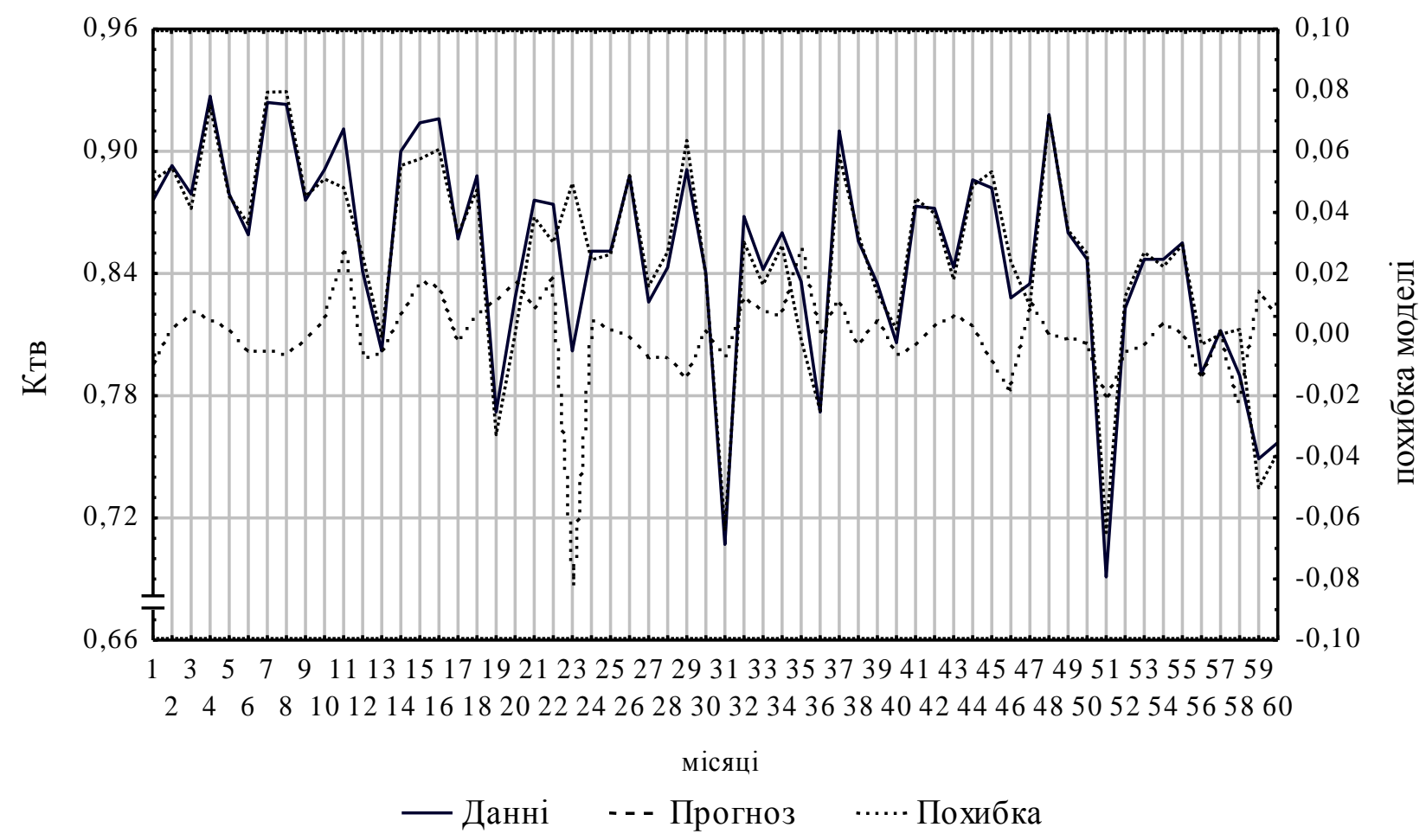

Рис. Зміна коефіцієнта технічного використання ЕУ тепловозів

Прогнозна крива, побудована на підставі регресійної моделі, проходить досить близько від вихідної залежності. Єдина істотна розбіжність припадає на 23-й аналізований місяць (листопад), що може служити вказівкою на "викид", тобто зменшення $K_{\text {тв }}$ нижче середнього рівня й вимагає проведення детального аналізу причин такого зниження.

Висновки і перспективи розвитку

1. Розглянутий метод множинної лінійної регресії зі стохастичними та структурними змінними може бути використаний для аналізу зміни показників надійності ЕУ тепловозів залежно від сезону їі експлуатації.

2. На основі аналізу фіктивних змінних в одержаній регресійній моделі визначено, що значення $K_{\text {тв }}$ ЕУ тепловозів статистично значущо знижаються у квітні та листопаді місяцях.

3. Застосування фіктивних змінних у рівняннях регресії дозволило кількісно оцінити величину та значущість сезонних 
коливань показників ЕУ тепловозів, що створює обгрунтовані передумови до сезонного корегування регламенту робіт, які виконуються на ТО-3 та ПР-1. Окрім того, встановлено якісний зв'язок між факторами, що входять до регресійної моделі, та визначено найбільш значущі 3 них. Останнє дає змогу впливати на керовані фактори таким чином (будувати стратегію управління), щоб забезпечити належний рівень експлуатаційної надійності ЕУ тепловозів при мінімізації витрат на його підтримання.

\section{Список літератури}

1. Тартаковський, Е.Д. Системний підхід до сезонного регулювання локомотивних енергетичних установок [Текст] / Е.Д. Тартаковський, Д.С. Жалкін // Зб. наук. праць. Харків: ХарДАЗТ, 2000. - Вип. 44. - С. 48-55.

2. Тартаковський, Е.Д. Модель процесу експлуатації локомотивних енергетичних установок [Текст] / Е.Д. Тартаковський, Д.С. Жалкін // Зб. наук. праць. - К.: НТУ, 2002. Вип. 15. - С. 219-223.

3. Жалкін, С.Г. Підвищення енергетичної ефективності експлуатації тепловозів [Текст] / С.Г. Жалкін, Д.С. Жалкін // Зб. наук. праць. - Харків: УкрДАЗТ, 2009. - Вип. 111. C. 131-143.

4. Бокс, Дж. Анализ временных рядов. Прогноз и управление [Текст] / Дж. Бокс, Г. Дженкинс. - М.: Мир, 1972. - 295 с.

5. Боровиков, В. STATISTIKA: искусство анализа данных на компьютере. Для профессионалов [Текст] / В. Боровиков. - СПб.: Питер, 2001. - 656 с.

Ключові слова: тепловоз, енергетична установка, надійність, модель, прогнозування, технічне обслуговування, ремонт.

\section{Анотаціiі}

Запропоновано модель та проведено аналіз сезонних змін показників використання енергетичних установок тепловозів 3 метою підвищення надійності роботи за рахунок сезонного корегування процесів технічного обслуговування та ремонту.

Предложена модель и проведен анализ сезонных изменений показателей использования энергетических установок тепловозов с целью повышения надежности работы за счет сезонной корректировки процессов технического обслуживания и ремонта.

The model and the analysis of seasonal changes in indicators of diesel locomotives energy plants to improve the reliability by the seasonal adjustment process of maintenance and repair. 